haps we are losing our hair for the same reason that we are said to be losing our teeth; because they are no longer needed. The condition marks then but a step in the upward adjustment of the human form in advancing civilization. The early loss of the hair and teeth may yet be recognized as a sign of culture and refinement; and as was remarked some years ago in this Journal, the escutcheon of the future will have for a ground a hairless scalp with a decayed tooth rampant.

\section{THE MEDICAL SOCIETY OF THE STATE OF} NEW YORK.

The President, Dr. L. S. Prlcher, in his address delivered at the annual meeting in Albany, February 7, referred to the American Medical Association as follows :

The American Medical Association and State Representation.-I have the pleasure of presenting to this Society at this time a communication from Dr. William B. Atkinson, Permanent Secretary of the American Medical Association, transmitting a resolution adopted by that Association at its session held in Detroit, June, 1892, appointing a committee of five, instructed to meet a like committee from the State Medical Society of New York, and the State Medical Association of New York, for the purpose of adjusting all questions of eligibility of members of the State Medical Society of New York to membership in that Association, and notifying this Society that the committee had been appointed, consisting of Drs. N. S. Davis, of Illinois; John H. Rauch, of Illinois; William T. Briggs, of Tennessee; Dudley S. Reynolds, of Kentucky; and Willis P. King, of Missouri.

The evident intention of this resolution was to request that this Society appoint a similar committee to confer with the committee named, although the resolution as transmitted does not say so. It is difficult to see what purpose such a conference as is proposed could serve. The American Medical Association is very properly its own judge of what shall be the qualifications required of its members. It is a voluntary Association, responsible to no one, and may change its standard for admission at its will. At its session at St. Paul in June, 1882 , it voted that the Medical Society of the State of New York was not entitled to representation in it, because the Code of Ethics adopted by that Society essentially differed from, and was in conflict with, the Code of Ethics of the American Medical Association. The status of affairs to-day differs in no respect from what prevailed in 1882 , save that a year or two later the American Medical sissociation adopted an explanatory declaration which practically interpreted its own Code to mean the same as the Code already adopted by the Medical Society of the State of New York. It did not, however, rescind the vote of disfellowship adopted in 1862 , but, on the contrary, at the recent meeting in Detroit, renewed it and extended it, to embrace not only this Society as an organization, but also all persons who affiliated with it. At this same meeting, also, it appointed a committee to report upon the revision of its own Code of Ethics. There is therefore no certainty as to what the future Code of Ethics of the American Medical Association will be. It would be highly improper for the Medical Society of the State of New York to assume in any way to dictate to, or even suggest to, any oganization not subordinate to it, what ethical standard, if any, such an organization should adopt. It must content itself with regulating its own standards, as it now does, suggesting in turn that it is equally indelicate for organizations which have no supervising relation to it to extend advice as to its internal affairs. Practically the relations of the Medical Society of the State of New York to the American Medical Association are the same as those which it sustains to the British Medical Association, the Canadian and Ontario Medical Associations, and to the Medical Societies of the various adjacent States to which it is in the habit of sending delegates annually, viz.: the relations of courtesy and comity. All these medical organizations named continue to receive with due honor and respect the delegates appointed by this Society, and doubtless whenever the American Medical Association shall signify its desire that this Society shall again send delegates to its meetings, such delegates will be sent. The Medical Society of the State of New York, however, must meanwhile be content to do its own work in its own way, awaiting the pleasure of the Association in question. Nevertheless, since a failure by this Society to appoint such a committee as is contemplated in the communication from the American Medical Association, would doubtless be construed by many, who are still ignorant of the real relations which exist between the two organizations, as displaying a factious and quarrelsome spirit, and as a matter of simple professional comity, I would advise that a committee of five be appointed by this Society to meet the committee of the American Medical Asociation as requested.

The Present Code of Ethics.-In the course of the discussions which have been provoked by the action of the American Medical Association just alluded to, it has come to the knowledge of your President that many of the physicians of this State are convinced that in view of the present state of general enlightment prevailing throughout the State of New York, and the safeguards which by legal enactments are thrown about the entrance into the medical profession, it would comport more with the dignity of the medical profession, and would enhance the respect in which it is held by the general public if all specific rules of ethical conduct were elided from the by-laws of the State Medical Society, and if the regulation of such matters were hereafter left to the judgment of individual practitioners influenced by the well-known consensus of professional opinion and local custom in the places where the work of each is being carried on. Among a large number of representative physicians from all portions of the State with whom I have conferred on this point, I have found a singular unanimity of feeling on this subject. The only hesitancy which any have expressed has been as to whether it would be wise, since practically this is already the present status of the profession in this State, to make any movement looking to a formal revision of a Code from our bylaws, lest it should revive acrimonous discussion, and reawaken strife that would be detrimental to the higher interests of the profession in this State. By far the greater weight of the opinions which I have 
been able to elicit has, however, been that no such result would follow; but that, on the contrary, such action would tend still more to heal old differences and bring together all the elements of medical profession in this State. Suc is also my own mature opinion, and further, it has seemed to me that at present, where there is a general revival of interest in the matter of professional ethics, as is evidenced by the discussions which are now going on in the medical journals of the country, and when this question of Code is again unavoidably brought to the attention of this Society, that it is a specially favorable moment for taking this final step. At the present time the only allusion in the by-laws of this Society to a system of Medical Ethics is the very brief $\S 8$ of Chapter VI., which merely says :

"The system of medical ethics adopted by this Society. February 7, 1882, shall be considered authoritative to govern the medical profession in the State of New York."

I would recommend that this section be dropped in toto. The effect of such action would be to leave this State Society without any formulated Code of Ethics, and to relegate the Code of 1862 , together with that of 1847 and 1823 , to the domain of history, though ever remaining of interest and value to the student of the development of ethical standards in the medical profession of this State.

Report of Committee on the President's Address.-Dr. VANDER VEer read the report. It recommended the following:

That the Society reserves to itself the right to punish its members for any unprofessional conduct.

The determination of what shall be considered unprofessional conduct shall rest with the Society. If at any time charges are preferred against a member of the Society, these charges are referred to a committee which already exists for a-similar purpose. This rule shall take the place of paragraph eight of chapter six of the by-laws, as well as the rules adopted by this Society in February, 1882.

Resolved, That the Society deems it unwise, at this time, to appoint any committee of conference with the American Medical Association upon the subject of medical ethics, as requested by that distinguished body; but the Society ventures to express the hope that the American Medical Association, at no distant day, will take such actions as will remove the merely technical obstacle to the most cordial coöperation between the two societies.

The New York Medical Journal refers to this action as follows:

At the meeting of the Medical Society of the State of New York held this week the general endorsement of the recommendations contained in the president's inaugural address was followed by specific action by which the society's Code of Ethics was extinguished. This, of course, freed the Society from any obligation to delegate a committee of conference to meet the American Medical Association's special committee appointed to consider ways and means of reëstablishing relations between the two organizations. The situation seems, therefore, to be somewhat improved; the State Society has no Code of Ethics, and consequently is less at variance with the American Medical Association than when it had a Code that positively clashed with the Association's code. It remains to be seen, however, whether other relations between the two bodies than those of "comity" will again come into existence.

In this action of the New York State Medical Society there seems to be a rolling back and away of the clouds and mists that have obscured the relations of that organization with the American Medical Association.

We look hopefully to the committee appointed by the American Medical Association at its last meeting, to report for the approval of and adoption by that organization of a code of ethics, constitution and by-laws, that will be acceptable and provide an organic law that will make possible a unification and membership in one body of every practitioner of rational medicine in this country.

An Army Medical Board will be in session in New York City, N. Y., during April, 1893, for the examination of candidates for appointment to the Medical Corps of the United States Army, to fill existing vacancies.

Persons desiring to present themselves for examination by the Board will make application to the Secretary of War, before March 15, 1893, for the necessary invitation, stating the date and place of birth, the place and state of permanent residence, the fact of American citizenship, the name of the medical college from whence they were graduated, and a record of service in hospital, if any, from the authorities thereof. The application should be accompanied by certificates based on personal knowledge, from at least two physicians of repute, as to professional standing, character, and moral habits. The candidate must be between 21 and 28 years of age, and a graduate from a Regular Medical College, as evidence of which, his Diploma must be submitted to the Board.

Further information regarding the examinations may be obtained by addressing the Surgeon General U.S. Army, Washington, D. C.

C. Sutherland,

Surgeon General U. S. Army.

\section{BOOK REVIEWS.}

International Clinics: a Quarterly of Clinical Lectures on Medicine, Neurology, Pediatrics, Surgery, GenitoUrinary Surgery, Gynecology, Opthalmology, Lary gology, Otology, and Dermatology. By Professors and Lecturerers in the leading Medical Colleges of the United States, Great Britain, and Canada: Edited by JoHN M. Keating, R. D., Colorado Springs, Col., Fellow of the College of Physicians, Philadelphia, etc., Judson Daland, M. D., Philadelphia, Instructor in Clinical Medicine, and Lecturer on Physical Diagnosis and Symptomatology in the University of Pennsylvania, ete., J. Mitchel BRUN, M. D., F. R. C. P., London, England, Physician and Lecturer on Therapeuties at the Charing Cross Hospital, D. W. FinLAY, M. D., F. R. C. P., Aberdeen, Scotland, Professor of Practice of Medicine in the University of Aberdeen, etc. Vol. III. Second Series, 1892. Philadelphia. J. B. Lippincott \& Co.

There are 53 contributors to this volume on 77 subjects, filling 393 pages. The 24 plates are mostly well made, and there are 40 figures. The sections are apportioned as follows : medicine, 118 pages, surgery, 66 , neurolgy, 60 , gynecology and obstetrics, 58. ophthalmology and otology, each 19, pediatries, 17, dermatology 15, laryngology and rhinology, 9 , genito-urinary surgery 7 .

The initiatory lecture is by Dr. Wm. Pepper, on conges- 